\title{
Technical Efficiency of Gambir Farming in Lima Puluh Kota Regency, West Sumatra, Indonesia
}

\author{
Fauziah $^{a^{*}}$, Hasnah $^{b}$, Rusda Khairati ${ }^{b}$ \\ a Student of the Graduate Program, Universitas Andalas, Kampus UNAND Limau Manis Padang, West Sumatera \\ 25163 Indonesia \\ ${ }^{b}$ Faculty of Agriculture, Universitas Andalas, Kampus UNAND Limau Manis Padang, West Sumatera 25163 \\ Indonesia
}

\section{ARTICLE INFORMATION}

Article history:

Received:

Revised:

Accepted:

Keywords:

Gambier, technical efficiency, stochastic frontier, Cobb Douglas

Correspondence:

Phone: +6282382370223

E-mail:

ejifauziah30@gmail.com

\begin{abstract}
A B S T R A C T
This study analyzes the factors influencing gambier productivity, analyzes the technical efficiency of gambier farming, and analyzes the factors affecting gambier farming's technical efficiency. This research was conducted in Lima Puluh Kota Regency, a gambier production center in West Sumatra. Data were analyzed using the Cobb Douglas stochastic frontier production function. The results showed that the factors that significantly influenced gambier's productivity were labor, NPK fertilizer, plant age, number of trees, varieties, and technology. The number of labor, fertilizer factor, plant age, number of trees, and seedling varieties had a positive effect on gambier productivity. In contrast, NPK fertilizer and technology had a negative impact on gambier productivity. The technical efficiency level of gambier farming started from 0.25 to 0.99 with an average level of 0.76 . It means that farmers are technically efficient but can still increase gambier productivity if they use production inputs appropriately and adequately. Factors that significantly influence technical efficiency are age, farming experience, and technology. Older farmers will have a higher level of technical efficiency compared to young age. The lower the farming experience, the more technically efficient the farmer is. Farmers who use the hydraulic jack system technology are more efficient than farmers who use the jack system technology.
\end{abstract}

(C)2020

Lima Puluh Kota Regency, as the main center of gambier plants in West Sumatra, has not been able to provide significant contributions or revenues, both for the region and for the farmers themselves (Afrizal , 2009). Until now, there are still many problems faced in the development of gambier. The main problem in the development of gambier 
is the low productivity and quality of products as a result of the handling of gambier business by farmers from upstream to downstream is still traditional, or the way to grow crops and postharvest processing is not optimal because of the lack of technological support. The needed technological support in the form of information technology is limited in number and is still difficult to apply by farmers (Dhalimi, 2006).

There are three ways to increase production: to increase the area of land, to develop and adopt new technologies, and to use available resources more efficiently. Increasing gambier production through the addition of land area seems to be more difficult because the increase in population has increased agricultural land conversion into residential and industrial land. To develop and adopt new technologies, farmers have difficulty with limited capital and farmers' lack of technological innovation knowledge. In the short term, the application of the technology used will remain. Therefore the best way to increase production is to increase the use of available resources more efficiently in farming. Efficient farming will produce maximum production, so that it will affect productivity. Increased productivity can be achieved by increasing technical efficiency by increasing the use of production factors and improving factors that affect technical efficiency.

One that affects the production of dried gambier is the technology used during processing. It currently has developed four types of equipment that use technology, namely the jack press system, screw system, hydraulic jack system, and factory systems. The advantages of these tools are more efficient than traditional tools because they do not use human labor. In addition, to get higher quality and capacity, their handling is easier and able to provide higher pressure power (Dhalimi, 2006). This is supported by Pane's research (2011), which found that technology partially significantly affected dry gambier production. The regression coefficient of 130.126 shows that dry gambier production when processed using modern technology is higher with a difference of 130.126 $\mathrm{kg} / \mathrm{ha} /$ year compared to dry gambier production when processed using simple/traditional technology.

Previous research on the use of gambier processing technology only measured the influence of factors of production; there is no research that measures the efficiency of gambier processing technology. Therefore, further research is needed related to the measurement of the technical efficiency of this gambier processing technology. The purpose of this study is to analyze the factors that influence the productivity of gambier, analyze the level of technical efficiency of gambier farming, analyze the factors that affect the technical efficiency of gambier farming.

\section{METHODS}

\section{Place and time of research}

This research was carried out intentionally (purposely) in Lima Puluh Kota District, which is a gambier production center area in West Sumatra. This research was conducted from May 2020 until June 2020.

\section{Research methods}

The method used in this study was a survey method. Data collection techniques by means of this survey carried out by interviewing respondents.

\section{Sampling Method}

The sample in this study was gambier farmer producers in the Lima PuluhCity area by using Multiple Stage Sampling. Then one district was chosen randomly, and Mungka District was chosen as the sample location. After obtaining the location of the Sub-district then the Nagari level was chosen again. The village selection was made randomly; the village being chosen was the village of Talang Maur.

According to (Usman \& Akbar, 2006), parametric statistical techniques require relatively large data, a minimum of 30 . The number of samples is determined after going to the field; the sample set of 50 samples has met the requirements because it is already greater than 30 . 


\section{Data analysis method}

\section{Analysis of the stochastic frontier production function}

Gambier production function in this study was approached using the Cobb-Douglas stochastic frontier production function. The choice of CobbDouglas production function form as an approach tool was based on consideration because the CobbDouglas function production function form reducing the occurrence of multicollinearity is homogeneous. Simple calculations can be made in the form of linear functions and are most widely used in research related to agricultural production. The form of Cobb Douglas stochastic frontier production function in this study is shown in the equation

$$
\begin{aligned}
& \operatorname{Ln} Y=\beta 0+\beta 1 \ln X 1+\beta 2 \ln X 2+\beta 3 \ln X 3+\beta 4 \ln X 4 \\
& +\beta 5 \ln X 5+\beta 6 \ln X 6+v i-u i
\end{aligned}
$$

Where:

$\mathrm{Y}=$ gambier productivity (ton / ha)

$\mathrm{X} 1$ = number of workers $(\mathrm{HOK} / \mathrm{ha} /$ year $)$

$\mathrm{X} 2=$ total NPK $(\mathrm{kg} / \mathrm{ha} /$ year $)$

$\mathrm{X} 3=$ age of gambier plant $(\mathrm{yr})$

$\mathrm{X} 4=$ number of trees (trees $/ \mathrm{ha})$

X5 = dummy variety ( $1=$ superior variety (Udang, Cubadak, Riau), 0 = non-superior variety (other than Udang, Cubadak, Riau)

X6 = dummy gambier processing technology $(1=$ using hydraulic jack technology, $0=$ using jack technology).

$\beta 0=$ intercept or constant

$\beta i=$ regression coefficient of production factors $/$ estimator parameters

vi-ui = error term (vi is the noise effect, ui is the effect of the technical inefficiency of the model)

\section{Technical Efficiency Analysis}

Analysis of technical efficiency can be analyzed by using the formula:
$T E i=\frac{Y i}{y i *}$

TEi is the technical efficiency of the i-th farmer, yi the actual output produced, And yi $*$ is the output of the frontier function. Technical efficiency values range between zero and one. This value is inversely related to the value of technical inefficiency, which also ranges between zero and one.

Factors that are suspected to influence the technical efficiency of gambier include the age of the farmer, farmer education, gambier farming experience, land status, farm status. The value of the distribution parameter (ui) effect of technical inefficiency in this study is shown mathematically by the equation

$u i=\delta 0+\delta 1 Z 1+\delta 2 Z 2+\delta 3 Z 3+\delta 4 Z 4$

$+\delta 5 Z 5+\delta 6 Z 6+\delta 6 Z 7$

Where:

$\mathrm{Ui}=$ effect of technical inefficiency

$\delta 0=$ constant

$\mathrm{Z1}$ = age of farmer (year)

$\mathrm{Z2}$ = farmer education (year)

$\mathrm{Z3}$ = gambier farming experience (years)

$\mathrm{Z} 4$ = dummy farming status $(\mathrm{d} 1=1$ main livelihood, $\mathrm{d} 1$ = 0 not main livelihood).

$\mathrm{Z5}=$ dummy variety $(\mathrm{d} 2=1$ superior variety (shrimp, cubadak and riau), d2 $=0$ non-superior variety (other than shrimp, cubadak and riau)

$\mathrm{Z6}=$ dummy gambier processing technology $(\mathrm{d} 1=$ 1 using hydraulic jack technology, d2 $=0$ using jack technology).

$\mathrm{Z7}=$ land area $(\mathrm{Ha})$

\section{RESULTS AND DISCUSSION}

Estimation of the Cobb-Douglas Production Function by the OLS Method 
Analysis of the Cobb Douglas production function by the OLS method was carried out on 50 respondents' compartments to calculate the coefficient of determination (R2) resulting from

Table 1. Estimating the Cobb Douglas Production Function by the OLS Method

\begin{tabular}{|c|c|c|c|}
\hline $\begin{array}{l}\text { Production Input } \\
\text { Variable }\end{array}$ & Coefficient & $\mathrm{t}$ & $\operatorname{Pr}>|t|$ \\
\hline Constanta & 3.474 & 3.49 & 0.001 \\
\hline $\ln$ (Labor) & $0.370^{*}$ & 2.21 & 0.033 \\
\hline $\ln (\mathrm{NPK}$ & $0.051 * *$ & 1.88 & 0.068 \\
\hline \multicolumn{4}{|l|}{ Fertilizer) } \\
\hline ln (Plant Age) & $0.140^{*}$ & 2.98 & 0.005 \\
\hline $\begin{array}{l}\ln \text { (Number of } \\
\text { trees varieties) }\end{array}$ & 0.094 & 0.66 & 0.514 \\
\hline Varieties & $0.286^{*}$ & 3.59 & 0.001 \\
\hline Technology & 0.051 & 0.28 & 0.783 \\
\hline R-Square & 0.581 & & \\
\hline Adj R-Square & 0.523 & & \\
\hline
\end{tabular}

the equation. Following data are the results of the estimation of the Cobb Douglas production function by the OLS method.

Based on the results of the data analysis above, the R-Square determination coefficient is 0.581, meaning that $58.1 \%$ of the resulting gambier productivity variations can be explained by the independent variables used in the estimation of production function models, while $41.9 \%$ is explained by the variables other than the equation model. Furthermore, this production function model is analyzed with the stochastic frontier production function approach.

From the results, it can be seen that Labor (X1), Plant Age (X3), and Variety (X6) have a significant effect on the productivity of gambier at $\alpha$ level of 5 percent, and NPK Fertilizer (X2) have a significant effect on the level of $\alpha 10$ percent. In contrast, the Number of Trees (X4) and Technology (X6) did not significantly influence the productivity of gambier in the study area.

\section{Estimation of the Cobb-Douglas Production Function by the MLE Method}

The second stage is the estimation of the Cobb Douglas production function by the Maximum Likelihood Estimation (MLE) method. The estimation results with the stochastic frontier production function approach with the MLE method illustrate the best performance of the
Table 2 Estimation of the Cobb-Douglas Production Function by the MLE Method

\begin{tabular}{|c|c|c|c|}
\hline $\begin{array}{l}\text { Production Input } \\
\text { Variable }\end{array}$ & Coefficient & $\mathrm{z}$ & $P>|z|$ \\
\hline Constanta & -0.526 & -95.69 & 0.000 \\
\hline $\ln$ (Labor) & 1.021 & 1227.96 & 0.000 \\
\hline ln (NPK Fertilizer) & -0.028 & -399.02 & 0.000 \\
\hline ln (Plant Age) & 0.109 & 493.38 & 0.000 \\
\hline $\begin{array}{l}\text { ln (Number of trees } \\
\text { varieties) }\end{array}$ & 0.284 & 743.07 & 0.000 \\
\hline Varieties & 0.153 & 413.52 & 0.000 \\
\hline Technology & -0.048 & -183.78 & 0.000 \\
\hline
\end{tabular}

respondent farmers.

Based on the results of data processing above, it is obtained that all independent variables of labor, NPK fertilizer, plant age, number of trees, varieties, and technology have a significant effect on productivity dependent variables. This is indicated from the significance value, which was small than 0.05 .

The coefficient of labor, plant age, number of trees, and varieties had a positive influence on the productivity of gambier in Lima Puluh Kota District, while the variable NPK fertilizer and technology marked negative, meaning that NPK fertilizer and technology had a negative influence on the productivity of gambier in Lima Puluh Kota.

The limit production elasticity of worked variables had a positive and significant effect on gambier productivity with a coefficient value of 1.021, meaning that by adding 1 percent of the workforce with other inputs, it could still increase gambier 
productivity by 1,021 percent. The same results were found in (Afrizal , 2009), that the variable of labor had a very significant effect on the diversity of gambier production at the real level of $\alpha 1$ percent testing with an estimated parameter value of 0.98. Based on the results of research that laborers used gambier farmers consist of workers in the family and workers outside the family. Workers outside the family are used when harvesting and processing gambier because processing gambier must be done by workers who are already skilled, so that sometimes farmers hard to find skilled workers. This is supported by research conducted by (Sari \& Chairul, 2008), which states that a major problem being faced by the research area was the scarcity of laborers on gambier farming so that many gambier lands are abandoned. Scarcity of labor leads to high-wage labor in gambier farming.

The results of the NPK fertilizer variable had a negative and significant effect on the productivity of gambier with a value of -0.028 . This figure shows that increasing the amount of NPK fertilizer by 1 percent with other inputs will still cause a decrease in gambier productivity of $-0,028$. This is presumably because the respondent farmers' gambier crops had been given organic fertilizer derived from processed gambier pulp. NPK fertilizer was used only under certain conditions and only applied once per year. This was also due to the limited funds of farmers to buy fertilizers and the assumption of some farmers that chemical fertilizer, in the long run, will make production go down and will also make the gambier soil become arid. In addition, the factor of land distance from distant settlements and land in the mountains, inadequate road infrastructure, which makes it difficult for farmers to fertilize with chemical fertilizers. This result is supported by (Nasution , 2015), which states the reasons that caused farmers not to fertilize due to the characteristics of gambier plants that did not require special care. In addition, the difficulty of accessing land made fertilizer distribution activities more difficult. On the other hand, limited capital also caused farmers not to conduct maintenance activities.
The plant age variable was found to have a positive and significant effect on productivity with a limit production elasticity value of 0.109 . This means that every 1 percent increased in the age of gambier plants that had produced would increase 0.109 percent productivity of gambier. Gambier plant age could reach 70 years, with a peak harvest at the age of 3-14 years. From the research results, the average age of plants owned by respondent farmers was 23.24 years, that are considered in the optimal production period.

The result of the variable number of trees had a positive effect on the productivity of gambier with a value of 0.284 , meaning that each addition of the number of trees producing gambier yields by 1 percent would increase gambier productivity by 0.284 percent. The number of tree gambier plants depended on the area of land and also the distance of planting used by farmers when cultivating gambier plants. In the study area, the average number of trees owned by farmers was 1325.4 trees. The coefficient of varieties owned by the respondent farmers was positive and had a significant effect on the productivity of gambier with a value of 0.153 . This means that the use of superior varieties (cubadak, shrimp, and Riau) would increase gambier productivity by 0.153 percent.

The coefficient of gambier processing technology variables had a negative and significant effect on the productivity of gambier with a value of -0.048 . This figure shows that the use of hydraulic jack technology would reduce productivity by 0.048 percent. It may be caused by the distance of the hydraulic jack system press machine was located far from the respondent farmer's gambier garden, while the jack system press house was located directly in the respondent farmer's gambier garden. It had an effect on the length of the gambier leaf until it reached the hydraulic jack system. Gambier leaves would affect the amount of sap produced, and if the processing of gambier leaves is delayed, it will reduce the resulting sap (Zamarel \& Hadad, 1991). The technology used in this study, specifically on the press tool technology used, was the hydraulic jack and jack system. 


\section{Technical Efficiency Analysis}

The level of technical efficiency was between 0 and 1 , where 0 means very inefficient while one means very efficient. The farmer, technical efficiency value, was categorized quite efficient if it has a value of $\geq 0.7$ and categorized as not yet efficient if it has a value $<0.7$ (Kumbhakar, 2002). Based on the research results, the level of technical efficiency of gambier farming in Lima Puluh Kota Regency was between $0.25-0.99$. The average level of technical efficiency of gambier farmers was 0.76 , meaning that the productivity of gambier in the study area had reached $76 \%$ of the maximum limit productivity that could be achieved with the assumption that it was carried out with good management. This figure shows that the average respondent farmer was technically efficient, but the respondent farmer could still increase yields to the maximum as farmers who had the highest efficiency value. The following graph shows the level of technical efficiency of gambier farming in Lima Puluh Kota Regency.

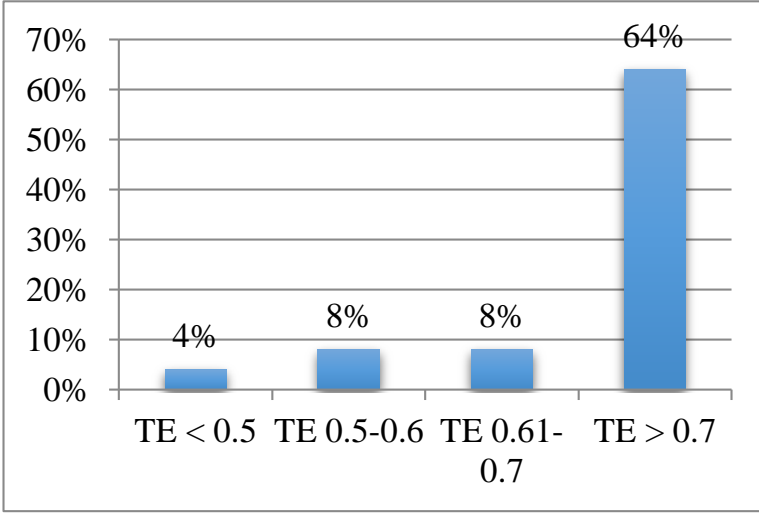

Figure 1. Graphic of the Technical Efficiency Level of Gambir Farm in Lima Puluh Kota District
As seen in Figure 1, 64 percent of respondent farmers were classified as technically efficient, 16 percent had 0.5-0.7 technical efficiency, and 4 percent of respondent farmers had low technical efficiency. To improve the technical efficiency of farming, farmers can increase production inputs that have a positive and significant effect on gambier productivity. The same research results were found by (Sari \& Chairul, 2008), who found the average level of technical efficiency of farmers who cultivated land continuously at 0.74 while farmers who cultivated land non-continuously at 0.45. Technical Efficiency Gambir Processing Technology used by respondent farmers consisted of two technologies, namely the hydraulic jack system technology and the jack system.

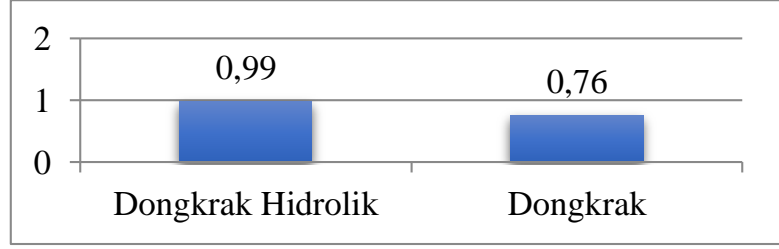

Figure 2. Graph of Average Technical Efficiency Level of Farmers Using Hydraulic and Jack Technology

Based on the results of research on the use of production factors, hydraulic technology variables had a positive effect on gambier productivity. The average value of technical efficiency of respondent farmers who used the hydraulic jack system technology was higher than farmers who used the jack system technology, namely with an average of 0.99 while the jack system with an average of 0.76 . This means that if farmers use the hydraulic jack technology, the jack system will increase the productivity of gambier, and also, the farmer will be technically efficient. 
Table 3. Estimating the Technical Inefficiency Effects of the stochastic frontier production function of gambier farming

\begin{tabular}{llll}
\hline $\begin{array}{l}\text { Production Input } \\
\text { Variable }\end{array}$ & Coefficient & $\mathrm{z}$ & $\mathrm{P}>|\mathrm{z}|$ \\
\hline Constanta & 3.077 & 1.53 & 0.126 \\
Age (Z1) & $-0.097^{*}$ & -2.20 & 0.028 \\
Farmer Education & -0.108 & -1.06 & 0.287 \\
(Z2) & & & \\
Farming & $0.084^{*}$ & 2.36 & 0.018 \\
Experience (Z3) & & & \\
Farm Status (Z4) & -0.299 & -0.32 & 0.750 \\
Variety (Z5) & -0.343 & -0.55 & 0.585 \\
Technology (X6) & $-11.659^{*}$ & -2.26 & 0.024 \\
Land Size (X7) & $-0.227^{* *}$ & -1.80 & 0.072 \\
\hline
\end{tabular}

\section{Factors Affecting Gambir Farming Technical Efficiency}

Based on the results of research on the age factor of farmers who were negative, this can be interpreted as the age of gambier farmers increased in the study area, the level of technical efficiency of gambier farming was increasing and had a significant effect. This result was in line with the research of (Ibanah , 2014), which states that as farmers grow older, a farm will be more technically efficient, reasons such as the support of experience, education as they get older. This is also consistent with the research of (Gobel \& Zwick, 2009) that productivity will increase along with increasing age at productive age. Ninety-two percent of respondent farmers are farmers of productive age, which supports the age factor in this study significantly affecting the technical efficiency of gambier farming in Lima Puluh Kota District.

The education variable of respondent farmers had a negative sign and did not significantly influence the technical efficiency of gambier farmers. A negative sign means that the higher the education, the more technically efficient the farmer will be. This states that education is an important variable that can improve efficiency because the more advanced level of education, the farmers will increasingly add knowledge to adopt better cultivation technology and can use production inputs appropriately. This is supported by (Tinaprilla , 2013), which states, which means that the higher the education, the inefficiency will decrease, farmers with higher education will be more open in receiving information and easier to adopt or accept technological changes so that it will increase efficiency.

The farming practice was expected to be negative, meaning that more experience of farmers encourages farmers to be more technically efficient or minimize the effects of technical inefficiency. This is because the more experience of farmers in cultivation activities allowed farmers to be more efficient in carrying out farming activities because they already knew the cultivation activities better than other farmers who had just tried in the cultivation activities. However, based on the results of research in the field of gambier farming, the experience was positive and significant for technical inefficiencies, meaning that the longer the experience of farming, the more inefficient in gambier farming. This was thought to be caused by the factor of farmers' reluctance to try new things in production because they are already accustomed to the old way of production, which is done for generations. This result was in line with Sari's research (2017), which states that the long experience of respondents will increase the effect of inefficiency so that it can reduce the level of technical efficiency, which is better and more efficient. The method used is an old and hereditary method, and there is no change in ways of farming for the better and more efficient during the period of time the farming activities are carried out.

The estimation results of the inefficiency effect showed that farming status as a livelihood was negative but had no significant effect. These results indicated that farmers with primary livelihoods in gambier farming would reduce technical inefficiencies, meaning that farmers with main livelihoods for farming gambir would be more technically efficient than gambier farmers as a side income. This could happen because in the field, farmers who, as their main livelihood, grow gambier, will focus more attention on their 
gambier plants compared to farmers who work as side livelihoods, based on the results of gambier farmers' interviews as a side income only looking for free time to take care of their gambier plants. Whereas gambier farmers, as their main livelihood, will grow gambier directly and more often maintain their gambier plants so that they can produce well. These results are different from the findings of (Tinaprilla , 2013), who examined sugarcane commodity, finding that farming as the main livelihood would increase inefficiency or even more efficient farming. This can happen because most farmers are farmers with other commodities. They will focus more on the sugar cane if the rice is not successful because sugar cane is a competitive commodity with rice.

In this study, the variety factor had a negative coefficient but did not have a significant effect. These results indicated that farmers who used superior varieties were more technically efficient than farmers who did not use superior seeds. This result was supported by the research of (Tinaprilla , 2013). The use of labeled seeds would reduce inefficiency. This suggests that seed quality is an important variable that can improve efficiency. In terms of technology, the coefficient results are negative and have a significant effect. This shows that farmers who used hydraulic jack system technology were more efficient than those who used jack system technology. It may be due to processing using a hydraulic jack system is easier and faster in processing. The land area coefficient owned by the respondent farmers was negative and had a significant effect on the $\alpha$ level of 0.10 . This means that the more land owned by the farmer, the more technically efficient the farmer will be. However, this result was different from the results obtained by (Ariani, 2017), who found that the land area variable had no significant effect on technical efficiency and also according to (Soekartawi, 2002) stating that narrower land areas were often more efficient because of the better supervision of production factors, adequate labor work and the availability of venture capital. But in reality, the results found in the field that the wider the farmer's field, the more efficient the gambier farmer. This is alleged because as many as 56 percent of the main livelihoods of respondent farmers are gambier farmers, so farmers can focus more on supervising their gambier plants.

\section{CONCLUSIONS AND RECOMMENDATIONS}

\section{Conclusion}

Based on the research objectives and the results of the discussion regarding the technical efficiency of gambier in Lima Puluh Kota District, it can be concluded that:

1. Factors that significantly influence the productivity of gambier in Lima Puluh Kota Regency are labor, NPK fertilizer, plant age, number of trees, varieties, and technology. Worked fertilizer factor, plant age, number of trees, and varieties had a positive effect on gambier productivity, while NPK fertilizer factor and technology had a negative impact on gambier productivity.

2. The level of technical efficiency of gambier farming in Lima Puluh Kota Regency started from 0.25 to 0.99 with an average level of technical efficiency of 0.76. This means that farmers were technically efficient but could still increase gambier productivity if they use production inputs properly and appropriately.

3. Factors that significantly influence technical efficiency were age, farming experience, and technology. Older farmers would have a higher level of technical efficiency compared to young age. The lower the farming experience, the more technically efficient the farmer was. Farmers who used the hydraulic jack system technology were more efficient than farmers who used the jack system technology.

\section{Recommendations}

As for suggestions for respondent farmers who have used the hydraulic jack system technology to find solutions related to the distance between the garden and the felt house in order to increase the 
production of gambier sap. And also, for farmers who have not used the jack system press tool, it is better if there is capital available to adopt the hydraulic jack system technology so that farmers are technically efficient

\section{REFERENCES}

Afrizal , R. (2009). Analisis Produksi Dan Pemasaran Gambir Di Kabupaten Lima Puluh Kota Provinsi Sumatera Barat. Bogor: Institut Pertanian Bogor.

Ariani, E. (2017). Efisiensi Teknis Usahatani Kakao pada Pola Tanam Polikultur. Bogor: Institut Pertanian Bogor.

Dhalimi, A. (2006). Permasalahan Gambir (Uncaria gambir L) di Sumatera Barat dan Alternatif Pemecahannya. Indonesia: Balai Besar Pengkajian dan Pengembangan Teknologi Pertanian.

Gobel , C., \& Zwick , T. (2009). Age and Productivity: Evidence from Linked Employer-Employee Data. ZEW Discussion Papers.

Ibanah . (2014). Tingkat Efisiensi Teknis Usahatani Kedelai di Kabupaten Jember. Bogor: Prosiding Seminar Nasional; Kristalisasi Paradigma Agribisnis dalam Pembangunan Ekonomi dan Pendidikan Tinggi.

Kumbhakar , C. S. (2002). Specification and Estimation of Production Risk, Risk Preferences, and Technical Efficiency. American Journal Agricultural Economic.

Nasution , A. H. (2015). Peran Kelembagaan dalam Pengolahan dan Pemasaran Gambir di Kabupaten Lima Puluh Kota Sumatera Barat [Tesis]. Bogor: Institut Pertanian Bogor.

Sari, H., \& Chairul. (2008). Analisis Efisiensi Teknis Usaha Tani Gambir Di Kenagarian Simpang Kapuk Kabupaten 50 Kota. Jurnal Agribisnis Kerakyatan, 48-58.
Soekartawi. (2002). Analisis Usahatani. Jakarta (ID): Penerbit Universitas Indonesia (UIPress).

Tinaprilla , N. (2013). Analisis Efisiensi Teknis Usahatani Tebu Di Jawa Timur. Bogor: Departemen Agribisnis, Fakultas Ekonomi dan Manajemen, IPB.

Usman, H., \& Akbar. (2006). Metodologi Penelitian Sosial. Jakarta: PT Bumi Aksara.

Zamarel , \& Hadad. (1991). Budidaya Tanaman Gambir Edisi Khusus Penelitian Tanaman Rempah dan Obat. 